\title{
Clinical evaluation of the T. pallidum haemagglutination test
}

\author{
TETSUO UETE, SADAYO FUKAZAWA, KAOKO OGI, AND YOKO TAKEUCHI \\ Kitano Hospital, Tazuke Kofukai Medical Research Institute, Kita-ku, Osaka City, fapan
}

Since the fluorescent treponemal antibody absorption test (FTA-ABS) became available in 1964 it has, in a number of areas, become a standard test with the advantages of greater sensitivity and specificity than tests using cardiolipin antigen (Hunter, Deacon, and Meyer, 1964; Meyer-Rohn, 1964; Petzoldt and Tupath-Barniske, 1965; Knox, Short, Wende, and Glicksman, 1966; Deacon, Lucas, and Price, 1966; Nicholas, 1967; Johnston and Wilkinson, 1968). The $T$. pallidum haemagglutination (TPHA) test has also been developed (Rathlev, 1965, 1967; Tomizawa and Kasamatsu, 1966; Cox, Logan and Norins, 1969), and its specificity and sensitivity have been established, but the effect of the therapy of syphilis on this test is not well known. In the present investigation, a clinical evaluation of the TPHA test was made in which it was compared to the VDRL slide test, the RPCF test, and the Wassermann reaction with respect to its sensitivity and the evaluation of the effectiveness of therapy.

\section{Material and Methods}

(1) The Wassermann reaction (WR) was carried out by the method of Ogata (1956), which is a modification of the original method of Wassermann, Neisser, and Bruck (1906), using reagents obtained from the Sumitomo Chemical Company, Japan.

(2) The VDRL slide test was performed by the method of Harris, Rosenberg, and Riedel (1946) and Harris, Rosenberg, and Del Vecchio (1948), using the same reagents.

(3) The RPCF test was carried out by the method of Cannefax and Garson (1957), using reagents supplied by the Nihon Toketsu Kanso Company, Japan.

(4) The TPHA test was carried out by the method of Tomizawa and others (1966) and Tomizawa (1968), using reagents commercially available for a manual test (TPHA, Fuji Zoki Pharmaceutical Company, Tokyo). The lyophilized reagents were reconstituted and the tests were performed according to the manufacturers' instructions with the addition that specificity was increased by removing group antibodies from the serum by absorption

Received for publication March 3, 1970 with Reiter treponemes. The haemagglutination wa then carried out using formol-treated, tanned sheep erythrocytes which had been sensitized with cell components of $T$. pallidum (Nichols strain).

\section{Results}

COMPARISON OF VDRL, WR, RPCF, AND TPHA TESTS IN VARIOUS PATIENTS

These four tests were carried out simultaneously upon the same serum specimens obtained from a number of patients in this hospital. In 105 sera, which gave positive results in at least one test, positive reactions were found in $92,62,55$, and 93 sera respectively. This indicates that the VDRL and TPHA tests were equally the most sensitive ( 88 per cent. positive). The positivity rate was 59 per cent. for the WR and 52 per cent. for the RPCF (Table I).

Comparing the cardiolipin antigen tests (VDRL and WR) with the $T$. pallidum antigen tests (RPCF and TPHA) of sixty sera with both cardiolipin tests positive, ten were negative to RPCF and six to TPHA; these included five sera which were negative to both. On the other hand, among eleven sera negative to both cardiolipin tests, the RPCF was positive in one and the TPHA in all (Table I).

TABLE I Comparison of serological reactions for syphilis in 105 human sera

\begin{tabular}{|c|c|c|c|c|c|}
\hline \multicolumn{4}{|c|}{ Serological reactions } & \multirow{2}{*}{$\begin{array}{l}\text { No. of } \\
\text { cases }\end{array}$} & \multirow{2}{*}{$\begin{array}{l}\text { Percentage } \\
\text { positive }\end{array}$} \\
\hline$V D R L$ & $W R$ & $R P C F$ & $T P H A$ & & \\
\hline+ & + & + & + & 49 & 46 \\
\hline+ & + & - & - & 5 & 5 \\
\hline+ & + & - & + & 5 & 5 \\
\hline+ & + & + & - & 1 & 1 \\
\hline+ & - & - & + & 24 & 23 \\
\hline+ & - & - & - & 5 & 5 \\
\hline+ & - & + & + & 3 & 3 \\
\hline- & + & - & - & 1 & 1 \\
\hline- & + & + & + & 1 & 1 \\
\hline - & - & - & + & 10 & 9 \\
\hline - & - & + & + & 1 & 1 \\
\hline 92 & 62 & 55 & 93 & 105 & 100 \\
\hline
\end{tabular}


EVALUATION OF THE FOUR TESTS BEFORE AND AFTER THE TREATMENT OF SYPHILIS

A comparison of the effect of therapy on the results of the four tests was made in six patients. The TPHA test continued to give positive results, but the WR and VDRL rapidly became negative (Table II). When additional cases of treated syphilis were studied, the initially positive VDRL and WR reverted to negative in some cases and remained positive in others, but the TPHA remained persistently positive in all cases, indicating that the effect upon it of syphilis therapy was less marked.

COMPARISON OF ANTIBODY TITRES TO CARDIOLIPIN AND $T$. pallidum ANTIGENS IN HUMAN SERA

Antibody titres to both types of antigen were carried out on sera from various cases of untreated and treated syphilis (Figure). When the titres were relatively low, no correlation was observed between the cardiolipin and $T$. pallidum antigens, but the WR and VDRL titres were closely correlated. However, when the antibody titres were very high (e.g. over 300 in the WR and over 10,000 in the TPHA), the WR or VDRL and the TPHA did show a correlation.

\section{Comments}

In this study, a comparison of the VDRL, WR, RPCF, and TPHA tests using human syphilitic sera, the VDRL and TPHA were equally the most sensitive procedures. This observation is in agreement with the experimental findings of Cox and others (1969) in chimpanzees and rabbits infected with $T$. pallidum. They reported that the TPHA test became reactive at approximately the same time
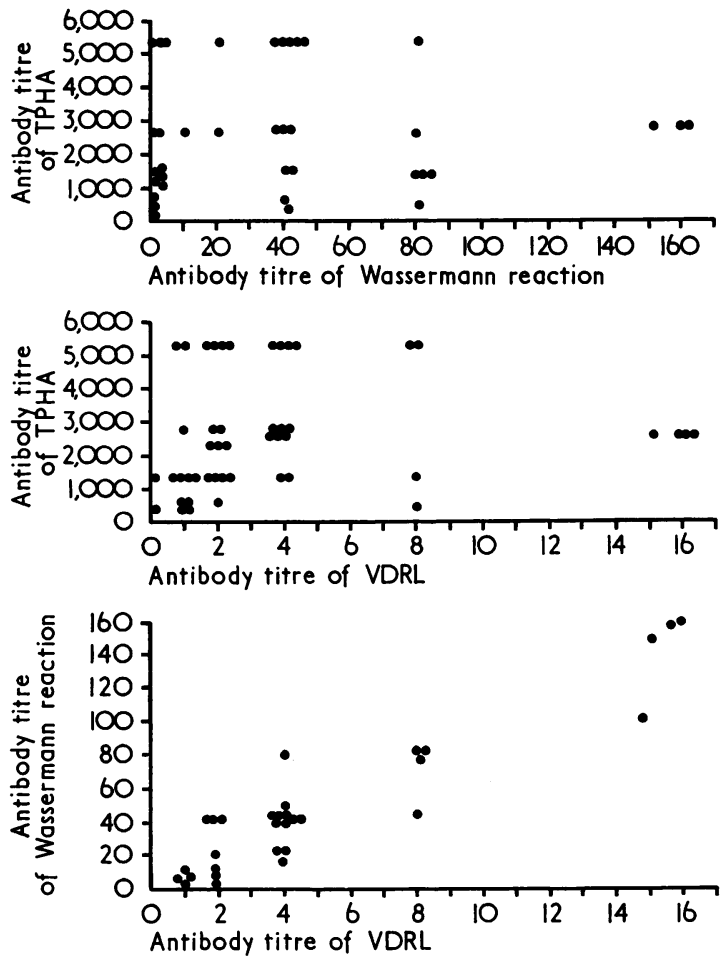

FIGURE Comparison of antibody titres to cardiolipin and $\mathrm{T}$. pallidum antigens in human sera

after infection as the VDRL or FTA-ABS tests. In rabbits infected with $T$. pallidum, the haemagglutination test became reactive as early as or earlier than

TABLE II Effect of antisyphilitic treatment on various serological reactions in six cases

\begin{tabular}{|c|c|c|c|c|c|c|c|}
\hline \multirow[b]{2}{*}{$\begin{array}{l}\text { Case } \\
\text { No. } \\
\end{array}$} & \multirow[b]{2}{*}{ Sex } & \multirow[b]{2}{*}{$\begin{array}{c}\text { Age } \\
\text { (yrs) }\end{array}$} & \multirow[b]{2}{*}{ Date of test } & \multicolumn{4}{|c|}{ Serological tests } \\
\hline & & & & $V D R L$ & $W R$ & $R P C F$ & TPHA \\
\hline 1 & $\mathbf{M}$ & 26 & $\begin{array}{lr}\text { January, } & 1967 \\
\text { June, } & 1968 \\
\text { February, } & 1969\end{array}$ & $\begin{array}{l}+ \\
-\end{array}$ & $\begin{array}{l}i- \\
-\end{array}$ & $\begin{array}{l}- \\
\overline{-}\end{array}$ & $\begin{array}{l}+ \\
+ \\
+\end{array}$ \\
\hline 2 & $\mathbf{F}$ & 30 & $\begin{array}{lc}\text { June, } & 1968 \\
\text { August, } & 1969\end{array}$ & $\stackrel{+}{-}$ & + & $\stackrel{+}{-}$ & $\begin{array}{l}+ \\
+\end{array}$ \\
\hline 3 & $\mathbf{F}$ & 37 & $\begin{array}{l}\text { October, } 1967 \\
\text { November, } 1968 \\
\text { December, } 1968\end{array}$ & $\begin{array}{l}+ \\
\dot{+} \\
-\end{array}$ & $\begin{array}{l}- \\
-\end{array}$ & - & $\begin{array}{l}+ \\
+ \\
+\end{array}$ \\
\hline 4 & $\mathbf{M}$ & 28 & $\begin{array}{lr}\text { August, } & 1967 \\
\text { July, } & 1968 \\
\text { December, } & 1968\end{array}$ & $\begin{array}{l}+ \\
+ \\
-\end{array}$ & $\begin{array}{l}+ \\
\dot{1} \\
-\end{array}$ & $\begin{array}{l}\dot{+} \\
+ \\
+\end{array}$ & $\begin{array}{l}\dot{+} \\
\dot{u} \\
\dot{+}\end{array}$ \\
\hline 5 & $\mathbf{F}$ & 35 & $\begin{array}{l}\text { October, } 1968 \\
\text { November, } 1968\end{array}$ & $\stackrel{+}{-}$ & $\overline{-}$ & $\overline{-}$ & $\begin{array}{l}+1 \\
+\end{array}$ \\
\hline 6 & $\mathrm{~F}$ & 30 & $\begin{array}{l}\text { March, } \\
\text { March, }\end{array}$ & $\begin{array}{l}+ \\
-\end{array}$ & $\begin{array}{l}+ \\
-\end{array}$ & $\stackrel{+}{-}$ & $\dot{+}+$ \\
\hline
\end{tabular}


the VDRL or FTA 1:5 procedure, whereas in chimpanzees the TPHA response appeared at about the same time as positivity in the FTA-ABS and VDRL tests. From our observations in man and those of Cox and others (1969) in animals, the VDRL, FTAABS, and TPHA tests can be considered the most sensitive tests for syphilis at the present time.

Rathlev (1967) reported that the TPHA test was highly specific for syphilis and that the results agreed with those of the TPI test. She studied fourteen biological false positive sera from patients with cancer, systemic lupus erythematosus, cerebral apoplexy, polyarthritis diabetes mellitus, hyperthyroidism, and leukaemia, and from pregnant women. All these sera showed positive Wassermann and Kahn reactions, but the results of the TPHA and TPI tests were negative. Many studies have indicated that the FTA-ABS test is also highly specific (Nielsen and Idsøe, 1963; Hunter and others, 1964; MeyerRohn, 1964; Petzoldt and Tupath-Barniske, 1965; Deacon and others, 1966; Knox and others, 1966; Nicholas, 1967; Johnston and Wilkinson, 1968). In both tests, specificity is increased by the absorption of nonspecific group antibodies from the serum by components of Reiter treponemes. The FTA-ABS test employs a fluorescent antigen-antibody reaction using the cell-components of $T$. pallidum (Nichols strain), whereas the TPHA test employs a haemagglutination reaction using $T$. pallidum (Nichols strain) sensitized erythrocytes. The correlation between the results of these two tests is extremely high (98 per cent.), although in primary syphilis the TPHA test has a slightly lower positivity rate (Shinokawa, Yokoyama, Inomata, and Ogata, 1968). The TPHA test is simpler and cheaper than the FTA-ABS test, and may thus be more practicable for routine use, as was pointed out by Rathlev (1967). An automated, quantitative microhaemagglutination assay for $T$. pallidum antibodies has been developed by Cox and others (1969), who emphasized its usefulness in the clinic and in the laboratory.

In the present study the TPHA test was evaluated in regard to the effect of therapy on the results of the test. Initially positive results in six cases of early syphilis remained positive after treatment, whereas positive WR and VDRL tests became negative; the longest period of observation was 2 years. Atwood, Miller, Stout, and Norins (1968) have similarly reported that the FTA-ABS test was still giving positive results after 13 years or more in 98 per cent. of patients who had been treated for syphilis, whereas the cardiolipin reagin tests remained positive in only 73 per cent. Mothershed, Yobs, and Clark (1957) reported that the FTA-ABS test in experimentally infected rabbits, once reactive, remained reactive even after curative treatment.

In our comparison of the antibody titres to the cardolipin and T. pallidum antigens in various syphilitic sera, we found a good correlation when the titres were very high but none when the titres were low. In the latter case there was a good correlation between the antibody titres of the WR and VDRL tests. The nature of this difference is not well understood and further studies are in progress.

\section{Summary}

The Treponema pallidum haemagglutination (TPHA) test was compared with the Reiter protein complement-fixation (RPCF) test, the Venereal Disease Reference Laboratory (VDRL) slide test, and the Wassermann reaction (WR) with respect to sensitivity and to the effect of therapy on the results. The TPHA and VDRL tests were equally the most sensitive of the four. In patients whose positive WR and VDRL tests quickly became negative after the treatment of syphilis, the positive TPHA test remained positive. A correlation between the antibody titres to $T$. pallidum and cardiolipin antigens was observed when the titres were very high, but there was no correlation when the titres were relatively low. The antibody titres of the WR and VDRL tests were well correlated, however, and the titres decreased after antisyphilitic treatment. The TPHA test thus appears to be a simple and sensitive method for diagnosis and for distinguishing biological false positive reactions. Its tendency to remain reactive in treated cases of syphilis, however, renders it unlikely to replace the WR and VDRL tests in the evaluation of therapy.

\section{References}

Atwood, W. G., Miller, J. L., Stout, G. W., and Norins, L. C. (1968) f. Amer. med. Ass., 203, 549

Cannefax, G. R., and Garson, W. (1957) Publ. Hlth Rep. (Wash.), 72, 335

Cox, P. M., Logan, L. C., and Norins, L. C. (1969) Appl. Microbiol., 18, 485

Deacon, W. E., Lucas, J. B., and Price, E. V. (1966) $\mathcal{F}$. Amer. med. Ass., 198, 624

HARris, A., Rosenberg, A. A., and RIEDEL, L. M. (1946), F. vener. Dis. Inform., 27, 169

$\longrightarrow,-$ and DeL VeCCHIO, E. R. (1948) Ibid., 29, 72

Hunter, E. F., DeAcon, W. E., and MEYeR, P. E. (1964) Fubl. Hlth Rep. (Wash.), 79, 410

Johnston, N. A., and Wilkinson, A. E. (1968), Brit. $\mathcal{F}$. vener. Dis., 44, 287

Knox, J. M., ShORT, D. H., Wende, R. D., and GlicksMAN, J. M. (1966) Ibid., 42, 16

MeYer-RoHN, J. (1964) Hautarzt, 15, 673

MOTHERSHEd, S. M., YobS, A. R., and ClARK, J. W., JR. (1967) Brit. F. vener. Dis., 43, 267 
Nielsen, H. A., and Idsøe, O. (1963) Acta path. microbiol. scand., 57, 331

Nicholas, L. (1967) Arch. Derm. (Chicago), 96, 324

Ogata, T. (1956) 'S erologic Diagnosis of Syphilis'. Nankodo, Tokyo

Petzoldt, D., and Tupath-Barniske, R. (1965) Dtsch. med. Wschr., 80, 950

RATHLEV, T. (1965) W.H.O. VDT/RES/77.65 (1967) Brit. F. vener. Dis., 43, 181

Shinokawa, Y., Yokoyama, T., INOMata, N., and Ogata, M. (1968) fap. F. clin. Path., 16, 907

Tomizawa, T. (1968) fap. F. clin. Med., 26, 304 , and Kasamatsu, S. (1966) fap. f. med. Sci. Biol., 19, 305

Wassermann, A., Neisser, A., and BruCK, C. (1906) Dtsch. med. Wschr., 32, 745

\section{Evaluation clinique du test d'hémaglutination du Treponema pallidum SOMMAIRE}

Le test d'hémaglutination du Treponema pallidum (TPHA) a été comparé à la réaction de fixation du complément à la protéïne Reiter (RPCF), à l'épreuve sur lame du Venereal Disease Reference Laboratory, à la réaction de Wassermann (BW) en ce qui concerne la sensibilité et la réponse du traitement. Dans les quatre cas, le TPHA et le VDRL furent les réactions les plus sensibles. Après traitement, le BW et le VDRL positifs devinrent rapidement négatifs, les TPHA positifs le restèrent. Lorsque les titres étaient très élevés, on observa une correlation entre les titres d'anticorps pour les antigènes tréponémiques et cardiolipidiques, mais il n'y eut pas de corrélation lorsque les titres étaient relativement kas. Les titres d'anticorps pour le BW et le VDRL étaient cependant en bonne corrélation et les titres baissèrent après le traitement antisyphilitique. Ainsi l'érreuve TPHA apparaît comme une méthode simple et sensible pour le diagnostic et la détection des réactions biologiques faussement positives. Cependant, sa tendance à rester positive dans la syphilis traitée ne la rend pas capable de remplacer le $B W$ et le VDRL pour suivre l'action du traitement. 